\title{
THE CULTURE OF LANGUAGE OR CULTURE IN LANGUAGE? THE QUESTION IN THE CONTEXT OF TEACHING POLISH AS A NON-NATIVE LANGUAGE
}

(THIS ARTICLE WAS TRANSLATED FROM POLISH BY JAKUB WOSIK)

Keywords: culture-focussed teaching of Polish as a non-native language, verbal anthropology, ethnolinguistics, culturemes, phraseology, forms of address, linguistic politeness, ritualisation of language

Abstract. This article discusses the modes of defining cultural content in teaching Polish as a foreign language. It proposes strategies for introducing cultural knowledge and knowledge about culture in the practice of teaching Polish as a non-native language. It seems appropriate to offer a division into:

1. The cultural semantics of lexemes, set phrases and expressions;

2. The culture (meaning the correct use) of expression and the linguistic norm; and

3. Culture content and areas conveyed to foreigners through the language they are learning.

This discussion fits the debate regarding the language which we teach to foreigners. In it, researchers have offered examples of semantic distortions (mostly shifts), and the dangers of private or rather extra-curricular linguistic contact with a language's native users. It also carries reflections on linguistic regionalisation and its presence in the practice of teaching Polish as a non-native language.

Researchers define the culture of language as an organised set of rules for using a language, rules, the application of which, ensures not only correctness, but also finesse. As a teaching subject, the culture of language is based on the theoretical foundations of normative linguistics. It recognises both sociolinguistic and pragmalinguistic conditions within the area of verbal communication. It indicates lexical tendencies: new words, collocations, expressions, borrowings, neologisms, etc. It interprets the ethics and the etiquette of linguistic conduct. Most of all, however, it indicates the relationships between language and culture. Because of that, the theory of the culture of language is perceived in an interdisciplinary manner. It would be difficult to state unequivocally whether it is rather a linguistic discipline

*p.garncarek@uw.edu.pl, Uniwersytet Warszawski, Wydział Polonistyki, Centrum Języka Polskiego i Kultury Polskiej dla Cudzoziemców POLONICUM, ul. Krakowskie Przedmieście 26/28, 00-927 Warszawa. 
or a practical skill. Either way it is usually arbitrary in nature, a fact which enables one to "pass judgements" in terms of norms and codifications in modern Polish. The answer to the question of why one should talk and write correctly in one's native tongue is so obvious that we have long ceased to search for it. That continues to produce ever more painful instances in media content, specialist texts (official documents in particular), chatrooms, blogs, text messages, etc., and mind you, this is not some mysterious knowledge. By applying a broader perspective to the culture of language one can easily avoid the spelling, punctuation, stylistic, lexical, and even articulatory "ailments", i.e. those linguistic "maladies" which often burden us in everyday situations and communicational events. The so-called "first impression" refers equally to one's appearance and kind of behaviour, and the way one uses language. It seems that the age-old rule "Say something and I'll tell who you are" has not lost any of its veracity. Obviously, one might at this point quote other maxims which further prove the fact that the language someone uses is a convincing statement about them. If one wishes to be viewed as a cultured person who possesses the virtues of the mind and the spirit, one needs to focus on the language one uses. There is no doubt about the fact that people evaluate the way others speak, their idiolect and their word choices, and the rules they follow for structuring their utterances. A person is ranked by others within a social hierarchy or within the axes of liking and respect. That natural mechanism of evaluation sometimes fails, e.g. when a person is faced with the phenomenon of verbalism or an excess of linguistic forms over the factual content of an expression, many examples of which can be found in the media or politics. Jan Miodek (capitalising on Ludwig Wittgenstein's thought) has argued that "good linguistic skills translate into more contacts with other people. They determine whether they are successful and convenient. Language should be considered the basic tool of one's existence within a society, and the limits of one's language are the limits of one's world. Why, we think in language. Work on language is the most efficient kind of work on thought, on our intellect," (Miodek 1983, p. 127). We view such care through the prism of its basic indicators:

Correctness, which is the pre-condition for a good and valuable message (oral or written). It indicates any and all departures from the accepted norms which pose problems for fully concentrating on the content of a message.

Skilfulness in using language, which indicates one's ability to utilise various styles and varieties of language, and to fit those to every possible communicational situation.

Aesthetics, which in spoken texts consists of one's care about an utterance and articulation, and of not using traces of dialect, jargon or forms considered profane.

Ethics, or rather the ethics of the spoken word, which consists of mutual respect between a sender and a recipient, and the respectful treatment of one another without imposing one's own views or resorting to manipulation, etc. 
The understanding of the culture of language as a skill of correct use of language is usually framed within the following categories:

- Linguistic etiquette - politeness-focussed linguistic behaviour marked by respect, kindness and interest in the facts conveyed by one's interlocutors;

- Linguistic innovation - the fact of describing and "listing" new elements of an expression;

- Linguistic correctness - the fact of using language in accordance with the accepted norms;

- Linguistic norm - linguistic habits within a narrower understanding (verification of correctness);

- Linguistic purism - excessive care for linguistic purity;

- Usus - a classification of correctness and incorrectness in a language.

The above description of the notions of the culture of language and its distinguishing features and categories only applies to the skills/competences of using one's mother tongue. It is worth considering to what extent that can be applied to the abilities of using a learnt language.

1. The culture of the Polish language as a non-native language has not yet received many studies in the Polish literature on teaching Polish as a non-native language. No separate catalogue of notions which exist in the curricula of teaching Polish as a foreign language (further referred to as PFL) has yet been devoted to it (cf. Janowska et al., 2016). Various related elements, such as politeness or linguistic norm, can be found identified in several catalogues: thematic, grammatical, and syntactic, catalogues of stylistic issues, and catalogues of functional and notional issues. They also exist in the descriptions of socio-linguistic or socio-cultural competences, and competences related to the knowledge of local life and institutions. Nearly 25 years ago the first and, as I can gather, the only study of selected issues in the culture or language was released, i.e. Elementy kultury języka w nauczaniu języka polskiego jako obcego na poziomie średniozaawansowanym [Elements of the culture of language in teaching Polish as a foreign language at the intermediate level] (Górecki, Koziej-Ruta, Paprotna 1998, p. 62).; it constituted a supplement to the curriculum of teaching PFL at the intermediate level. The topics in the classes devoted to the culture of language covered the following issues:

- pronunciation and accent;

- spelling and punctuation;

- linguistic correctness in terms of inflection, lexis, syntax, and phraseology;

- oral and written forms of expression;

- academic and technical language

(Górecki, Koziej-Ruta, Paprotna 1998, p. 62). 
Since then, the culture of language has not been distinguished in the curricula of teaching PFL, but rather it has been introduced in fragments and somewhat occasionally. The basic question one should pose at this point would be whether the culture of language should constitute a separate element of the process of teaching Polish as a foreign language and if so, what role it should then fulfil. Yet that is not the only question that comes to mind. Another should be: what language are we teaching foreigners? An attempt to find an answer starts to resemble a search for the golden mean, thus placing itself between linguistic norm and correctness introduced in class and the linguistic reality which exists almost everywhere outside the classroom.

Knowing the culture of the foreign language one is learning on the one hand protects one against the unwitting selection of lexis, local additions or profanity, but on the other, it forces one to exclude much from one's language. According to Kirsten Hastrup "not only is language (as a system) inseparable from its usage, but it is also (and for the same reasons) deeply embedded in the social. In short, and in spite of previous attempts to isolate it, it is non-autonomous" (Hastrup 2008, p. 47) [English version: K. Hastrup, A Passage to Anthropology: Between Experience and Theory, 1995, Routledge, New York]. The researcher has indicated that there is no sufficiently coherent morphosyntactic system which could have the exclusive right to that which is correct and normative in language while ousting from grammar that which constitutes any departure from the rules. According to her, such departures are not "systemic exceptions" but they rather constitute an integral part. Why would the principle be any different in a foreign language that is being learnt? The language taught at school and that heard in the street are the same language. A foreigner learning it needs knowledge regarding not only the rules related to correctness or etiquette, but also knowledge of the contextual and situational applications of diminutives, forms of address, profanity, colloquialisms, etc.

2. Pragmalinguistics, similarly to sociolinguistics, indicates the conditions in verbal communication. It constitutes a relatively new domain of linguistics which continues to expand its scope of study. Its interdisciplinary nature, which consists of various studies related to philosophy, logic, and psychology, is the reason why the teaching of the principles of the culture of language within the process of teaching Polish as a foreign language has been getting easier. That largely occurs through references to semantics. Yet the core of the study does not only cover the fields of significance (i.e. meaning), but also additional values (added meanings), i.e. the broad linguistic and extra-linguistic (verbal and non-verbal) contexts. Pragmalinguistics also means a focusing on speech acts and a definition of language users. Thus, the studied language (including a foreign one) is variable and dynamic, i.e. (to use a colloquial concept) living. Its authenticity is an outcome of correctness and usage norms, as well as of variant forms, jargon forms, obscenities, and emotionally marked forms. That constitutes a complete language, the teaching of which, in 
the practice of teaching Polish as a non-native language, occurs in any case, yet excessively outside of the classroom and the curriculum. Pragmalinguistics encourages users to enrich open (explicit) speech acts with closed (implicit) ones, which, in my opinion, is rarely considered in the methodology of teaching PFL. The dual nature of verbal communication built in an explicit and implicit manner enables one to establish more easily what in a foreign language is correct, cultured and normative, and what is best conveyed in a less direct manner utilising, e.g. euphemisms. It seems a rather effective manner of expanding one's knowledge about the culture of language and expertise in linguistic perception. Without the ability to develop hidden speech acts and metaphorical applications one would probably not be able to achieve satisfactorily high competence in the language one is learning.

\section{explicit + implicit use}

* Proszę, otwórz okno! [Please, open the window] Czy mogę prosić o otwarcie okna? [Could I ask you to open the window?]

Ale tutaj duszno! [Boy, it's stuffy in here] Może warto trochę przewietrzyć? [Maybe it would be worth airing this place?]

*Jaki on jest podobny do ojca. [Oh, how he resembles his father]

Skóra zdarta z ojca. [He's the spitting image of his father]

\section{implicit + explicit use}

* Nie udawaj Greka! [Don’t play possum!]

Nie udawaj, że nie wiesz o co chodzi! [Don't pretend you don't know what's it about!]

* Nie stój bezradnie jak cztery litery! [Don't stand there like the four letters you sit on!] Nie stój bezradnie jak dupa! [Don't stand there helpless like an arse!]

3. Presupposition - understood as the existing knowledge expected by teachers from learners - in the practice of teaching Polish as a non-native language applies more to cultural rather than linguistic areas. The latter are usually identified by using placement tests. It would be difficult to construct similar tests which could facilitate the evaluation of one's knowledge of culture. It is usually dispersed, selective, random even, and people acquire it not only through school education. Those are the main reasons why it is impossible to assess the existing level of one's cultural competence.

Much too often the practice of teaching Polish as a foreign language has proven that a glaring lack of basic information on Polish culture among foreigners does not in any way preclude the fact that they may possess extensive niche knowledge, such as in the plastic arts, the biographies of outstanding masters of culture, the history of Polish jazz or the Polish school of poster art. A selective absorption of linguistic competences is not possible within the process of learning a foreign language. Extensive expectations regarding socio-cultural knowledge, or knowledge about the people and institutions of a country which exist in foreign learners force teachers to modify lesson plans as they go. The fragments of 
general knowledge are not always equally common as one might expect. Often that becomes visible when making references to a common "lexicon of culture", which include such idioms as: Achilles' heel, Pandora's box, or labour of Sisyphus, unintelligible for learners from Asia or Africa. The difficulty consists in reading the culture codes which are unknown to foreigners who may come from distant cultural circles.

Cultural differences should not necessarily be associated with distance measured in kilometres (or miles). As an example, please consider the teaching of Polish forms of address to speakers of Swedish. Olof Palme, Swedish prime minister at the turn of the $1980 \mathrm{~s}$, introduced legal regulations which sanctioned the habit of referring to people within the "you" framework. There are no departures from the rule in Sweden (and not only there) which would result from diversity based on social status, age, profession, or academic status. Therefore, there are no linguistic means of decreasing or increasing the proxemic distance between interlocutors. One might assume that reducing forms of address to the "you" principle should be an obvious facilitation as then it is no longer necessary to identify a person's position, function, rank, father's name, etc. Yet that is a one-sided view, a fact which Swedish students helped me realise. In fact, the complexity of Polish forms of address offers a chance to display liking or dislike towards someone or signal the expected distance. The Swedish language is devoid of such a mechanism. Thus, diversity in cultural linguistic behaviour leads to hilarious and vague or even unpleasant communicational events. That is quite often the case during classes with learners of various nationalities. When I was conducting lectures at the Summer Polish-Austrian College, Polish students referred to me using the Pan + academic title (in the vocative) form but their Austrian colleagues addressed me simply Piotr (in the vocative). All I could do was respond in kind.

Since the discussed phenomenon becomes complicated by the evident gender asymmetry of Polish and the cultural diversity in this respect, the following examples refer to both women and men. These persons occupy the same positions, which is also quite uncommon. In the following examples, the forms of address were used by the persons' direct superiors. The characters include: Anna Kowalska (a secretary) and Jan Kowalski (a secretary).

* Define the professional relations between the director and his secretary (female):

Pani Kowalska

[Ms Kowalska]

Kowalska [Kowalska]

Pani sekretarko [Ms secretary]

Pani Anno [Ms Anna]

Pani Aniu. [Ms Ania (diminutive)] Aniu . . [Ania (diminutive)]

Stoneczko [Honey]

Kobieto [Woman] 
* Define the professional relations between the director and his secretary (male):

Panie Kowalski . . . . . . . . . . . . . . . . . . . . . . . . . [Mr Kowalski]

Kowalski. . .

[Kowalski]

Panie sekretarzu

[Mr secretary]

Panie Janie

[Mr Jan]

Panie Janku.

[Mr Janek (diminutive)]

Janku

Stoneczko

[Honey]

Człowieku. . .

.[Man]

Similarly to forms of address, greetings also clearly fulfil the function of establishing proxemic distance (closeness and distancing). Susanne Tienken has argued that:

greetings and good byes, e.g. Dzień dobry, Witam, Cześć, Halo, Pozdrawiam, Siema, Do widzenia, constitute an interesting example of communicational patterns; they are fulfilled in a more or less stereotypical manner yet they possess optional variants, and their selection is important for communication to be successful. Their meaning (which is often blurred) is less important than their function and performative power. The latter is an outcome of the fact that greetings are extremely often used as the titles of textbooks for learning a foreign language, and they usually constitute material for the initial lesson units during language classes, though no attention is devoted to their etymology. They are politeness-oriented forms, a fact which becomes clear when they are used unsuccessfully. (Tienken 2017, p. 53) [Unless indicated otherwise, English quotations were translated from Polish]

4. Swearing is an everyday habit of many natural users of language. When absorbing foreign languages, this is one of the abilities one acquires, to which I would without any hesitation refer as a skill. That does not mean that a foreigner has to do it. They should, however, possess the ability and knowledge regarding the load carried by words and phrases which are considered as abusive or insulting. Profanities, according to most linguists who study the interpretation of the culture of language, are not used for communication; their purpose is to offend others, which means they are an example of a lack of culture and they distort the process of communication. It fulfils the function of a means of expression, yet it forms a negative image of the person who uses it. The answer to the question why, then, one would still use it, is much more complex and does not always lead to condemning the person. Emma Byrne (2018) has formulated an interesting hypothesis, supported with examples from various domains of science, stating that we, as people, would never have become the most numerous species of primates had we not invented swear words. That is because the use of "words considered as vulgar in areas considered taboo" diminishes pain, strengthens bonds, develops one's creativity and efficiency, and helps find an outlet for one's internal tension. In her popular science study entitled Swearing Is Good for You, she has provided a series of scientific arguments in support of her hypothesis: 
- neurobiological, proving that swearing is an inseparable part of expressing emotions. Swear words are rooted in both brain hemispheres and in the amygdala (which is responsible for strong emotions);

- $\quad$ psychological, which build bonds between people with whom one wishes to share one's emotions;

- sociocultural, treating swear words as substitute elements for expressing sadness, fear or sympathy (mainly in men);

- physiological (the physiology of speech), which indicate swearing as a natural reaction to physical pain; and

- cultural, which prove a higher acceptance of profane behaviour in men rather than in women.

Byrne's studies have shown (importantly for this argumentation) that those of us who not only swear, but also do so in an elaborate manner utilising various expressions, possess a wider lexicon and higher linguistic competences that those who do not swear at all (cf. Byrne 2018). Therefore, one might consider including swear words in the practice of teaching Polish as a non-native language, regardless of whether one likes them or not, and seek ways of "taming" and reasonably indicating them. Instead of being ashamed of swearing, let us start, following Byrne's advice, doing it in a less constrained manner and more adequately to the situation. According to Benjamin K. Bergen "like all things, profane words eventually meet their end, ultimately fading away into banality and then obscurity," (Bergen 2019, p. 268) [English version: B.K. Bergen, What the F: What Swearing Reveals About Our Language, Our Brains, and Ourselves, 2016, Basic Books, New York]

5. Culturemes, i.e. lexical units with a semantic cultural taint, are a major dictionary resource in learning a foreign language. In it, they fulfil a dual role. Firstly, they enrich one's lexicon, and, secondly, they are the smallest carriers of cultural content within the structure of language. Of course, the notion of the culture of language covers a set of recommendations and norms which apply to all possible manifestations of linguistic operations: from enunciation, punctuation and spelling (cf. Karpowicz 2018), through inflection, word formation and syntax (cf. Jadacka 2005), to theories and the discussed lexical notions (cf. Markowski 2018). Yet from the perspective of teaching Polish as a non-native language, it is the absorption of lexis that seems most important. Note, however, culturemes are not only "set words" selected via a cultural key. According to Grażyna Zarzycka "a cultureme is a significant element of culture (rich in meaning, hence fulfilling the function of its interpreter), which can be indicated by both linguistic actions (words, sentences, texts) and non-linguistic actions (social behaviour, such as: facial expressions, gestures, and proxemic behaviour). However, the most common view posits that culturemes constitute the linguistic images of cultural meanings usually represented by lexical units" (cf. Zarzycka 2019, pp. 425-426). Therefore, 
it is important to include them as often as possible in teaching materials for teaching Polish as a non-native language. They are most easily introduced through lexis (nominal lexis in particular).

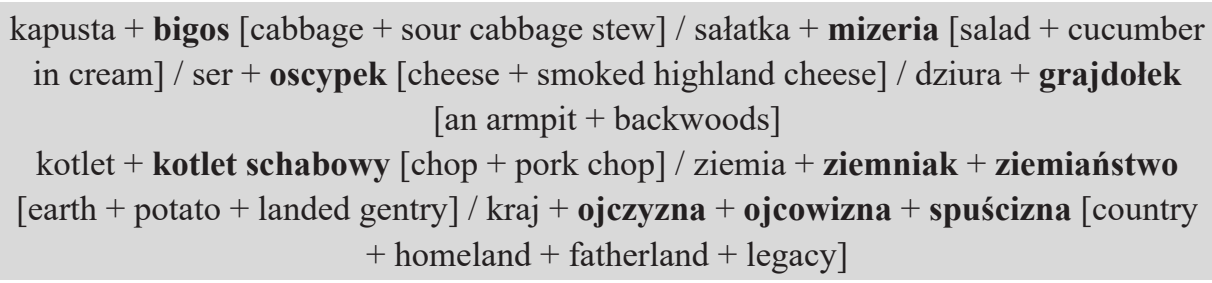

Culturemes in the ethnolinguistic approach preferred by the author are close to a self-stereotype, though they are not equivalent. Their stock or set of notions includes: national symbols (gościnność [hospitality], szlachta [the nobility], ziemiaństwo [landed gentry], ojczyzna [homeland]), national topography (Polska, Wawel, Jasna Góra, Giewont, Sybir, Westerplatte, Wista, Gniezno), endoethnonyms (Polak, Polka, Polak mały), names of values (Bóg [God], Jezus [Jesus], Matka Boża [Blessed Mary], honor [honour], pracowitość [diligence], wolność [freedom]), principles (bohaterstwo [bravery], patriotyzm [patriotism], przedmurze chrześcijaństwa [Bulwark of Christendom]), and the identifiers of cultural identity (bigos, bread, pork chops, vodka), as well as negative determinations (cham [a lout], cwaniak [hustler], kottun [a narrow-minded person], pijak [a drunkard], warchot [a brawler], ćwok [a pillock]) (cf. Rak 2015).

It is obvious that languages differ from one another in terms of their lexical stock. Those differences are not uniform nor always simply explainable. The translation of cultural content is particularly challenging. The relationships which exist between culture and the language in which it is expressed and described are a derivative of "collective mental creations", to use Edward Sapir's term. The stu$\mathrm{dy}$ and discussion of the culture of a language even with the ever more universal research tools always lead to culturally diverse results. It may be due to the fact that a foreign language, being absorbed, stops being "foreign" in communicational terms while only somewhat less foreign in cultural terms.

\section{BIBLIOGRAPHY}

Bergen B., K., 2019, What the F. Co przeklinanie mówi o naszym języku, umyśle i nas samych, Kraków.

Byrne E., 2018, Bluzgaj zdrowo. O pożytkach z przeklinania, Warszawa.

Górecki M., Koziej-Ruta J., Paprotna A., 1998, Elementy kultury języka w nauczaniu języka polskiego jako obcego na poziomie średnio zaawansowanym, in: Polonistyczna edukacja językowa i kulturowa cudzoziemców, Łódź. 
Hastrup K., 2008, Droga do antropologii, Kraków.

Jadacka H., 2005, Kultura języka polskiego. Fleksja, słowotwórstwo, składnia, Warszawa.

Janowska I., Lipińska E., Rabiej A., Seretny A., Turek P., 2016, Programy nauczania języka polskiego jako obcego. Poziomy A1-C2, Kraków.

Karpowicz T., 2018, Kultura języka polskiego. Wymowa, interpunkcja, ortografia, Warszawa.

Markowski A., 2018, Kultura języka polskiego. Teoria, zagadnienia leksykalne, Warszawa.

Miodek J., 1983, Kultura języka w teorii i praktyce, Wrocław.

Rak M., 2015, Co to jest kulturem, "LingVaria" X, 2(20), Kraków. https://doi.org.10.12797/ LV.10.2015.20.23

Tienkien S., 2017, Wzorce kulturowe a analiza kulturowa. Ujęcie teoretyczne $i$ metodyczne, in: W. Czachur (ed.), Lingwistyka kulturowa i międzykulturowa, Warszawa.

Zarzycka G., 2019, Kulturemy polskie - punkt widzenia, techniki ich wydobywania i negocjowania. Stosowanie perspektywy etnolingwistycznej w glottodydaktyce polonistycznej, in: "Acta Universitatis Lodziensis. Kształcenie Polonistyczne Cudzoziemców", vol. 26, G. Zarzycka, B. Grochala, I. Dembowska-Wosik (eds.), https://doi.org/10.18778/0860-6587.26.29

Piotr Garncarek

\section{KULTURA JĘZYKA CZY KULTURA W JĘZYKU? PERSPEKTYWA GLOTTODYDAKTYCZNA}

Słowa kluczowe: glottodydaktyka kulturowa, antropologia słowa, etnolingwistyka, kulturemy, frazeologia, zwroty adresatywne, grzeczność językowa, rytualizacja języka

Streszczenie. Artykuł dotyczy sposobów definiowania treści kulturowych w nauczaniu języka polskiego jako obcego. Są w nim zaproponowane strategie wprowadzania wiedzy kulturowej i wiedzy o kulturze w praktykę glottodydaktyczną. Wskazane jest (istotne zdaniem autora) rozróżnienie na:

1. semantykę kulturową leksemów, zwrotów i wyrażeń;

2. kulturę wypowiedzi i normę językową;

3. treści i obszary kulturowe przekazywane cudzoziemcom za pośrednictwem nauczanego języka.

Rozważania wpisują się w nurt dyskusji dotyczącej języka, którego nauczamy cudzoziemców. Przywoływane są w nim przykłady zaburzeń (zwłaszcza przesunięć) semantycznych, niebezpieczeństwa wynikające z prywatnych, a raczej pozalekcyjnych kontaktów językowych z jego naturalnymi użytkownikami. Zawarto również refleksję dotyczącą regionalizacji językowych i ich obecności w praktyce glottodydaktycznej. 